DOI https://doi.org/10.30525/978-9934-26-038-4-28

\title{
THE COMPARATIVE STUDY OF TWO EXPERIMENTAL MODELS OF GENERALIZED PERIODONTITIS IN RATS
}

\author{
Matvieienko L. M. \\ Assistant at the Department of Therapeutic Stomatology \\ State Institution «Dnipropetrovsk Medical Academy \\ of the Ministry of Health of Ukraine» \\ Dnipro, Ukraine
}

According to the WHO, generalized periodontitis is the sixth most common human disease. Now, it is proven that the main etiological factor in the development of inflammation in the periodontal tissues is qualitative and quantitative change in the microflora of the oral cavity, in particular the activation of periodontal pathogens [1]. However, the resistance of periodontal tissues to the pathogenic action of microorganisms is determined by systemic factors. In patients with severe concomitant pathology, the risk of periodontitis is much higher and its progress is more aggressive [2]. Meta-analyses of thirteen studies, comprising 49262 individuals, including 3197 diagnosed with diabetes, showed that diabetes increased the risk of incidence or progression of general periodontitis in $86.0 \%$ [3]. The most important long-term complications of periodontitis, associated with diabetes, are changes in bone metabolism [4]. The type II diabetes mellitus greatly impacts on the development of periodontitis by means of disorders in the metabolic and immune status, reducing general reactivity [5].

According to the results of clinical observations, the development of metabolic syndrome against the background of type- 2 diabetes mellitus is always accompanied by inflammatory-destructive processes in the periodontal tissues. In turn, to study the pathogenesis of disease for development of effective methods of treatment, there is a need to create its model, taking into account the effects of concomitant diseases [6].

The aim of this research is to compare two experimental models of general periodontitis in rats according the results of computer tomography.

Materials and methods. Experimental studies were conducted on 16 white male rats of Wistar line, aged 4 months, whose weight was 230-250 g, divided into research groups (the control and the main group) with experimental diabetes reproduced according two different methods.

In the control group the damage of the periodontal tissues was made with the introduction of xenobiotics Penicyllamine (Cuprenil ${ }^{\circledR}$, Teva, Poland, No series 16525016) at a dose of $20 \mathrm{mg} / \mathrm{kg}$ of rat body weight for 55 days 
(for 5 days, break 2 days) [7]. The use of Penicyllamine in the experimental model leads to the destruction of the periodontal connective matrix, in particular its main components - fibrillary proteins (collagen and elastins) and polysaccharides (proteoglycans and glycoproteins). Besides, the use of Penicyllamine causes significant activation of collagenase, which damages periodontal connective tissue due to its high complex-forming activity in relation to metal ions.

In the main research group, first of all, the experimental equivalent of type-2 diabetes was reproduced. After the previous 24-hour food deprecation (with free access to water), it was used a single intra-abdominal aqueous solution of Nicotinamide (Sigma-Aldrich, USA) $(230 \mathrm{mg} / \mathrm{kg}$ ) and 15 minutes after that - Streptozotocin (Sigma-Aldrich, USA) at a dose of $65 \mathrm{mg} / \mathrm{kg}$ as a $5 \%$ solution in the citrate buffer, $\mathrm{pH} 4.5$ [8].

The determination of glucose concentration was carried out using the Optium Omega glucometer (Abbott Diabetes Care Inc., USA) in blood obtained by scaring the tip of the animal's tail. Blood glucose levels were determined on the third day after introduction of drugs and 6-hour food disruption with free access to water. Only animals with elevated glucose $(8-14 \mathrm{mmol} / \mathrm{l})$ were used for further research.

On the 14th day, a re-measurement of glucose content was carried out to identify glucose tolerance disorders. Before the test, all animals of the control and research groups were subjected to 12-hour food depreciation with free access to water (glucose concentration was determined on an empty stomach), so this sample was considered as original (the control). Glucose was injected once orally in the form of $40.0 \%$ aqueous solution, at a level of $2.0 \mathrm{~g} / \mathrm{kg}$ of body weight. The dynamics of changes in blood glucose levels were estimated in the original state and 30, 60, 90 and 120 minutes after glucose intake. The results of the study of blood glucose levels was represented graphically in the form of the so-called «glycemic curve», assessed the levels of lifting of the glycemic curve at temporary intervals and its shape.

Only then, after the reproduction of type-2 diabetes, the periodontitis model was initiated drinking water with Penicyllamine (Cuprenil ${ }^{\circledR}$, Teva, Poland, No series 16525016) at a dose of $20 \mathrm{mg} / \mathrm{kg}$ of rat body weight, 7 days a week for 55 days, starting from 6 days [9].

On the 60th day of observation, the animals were withdrawn from the experiment by decapitation. In rats' heads bone mineral density of mandibles was studied with computer tomography (Planmeca ProMax 3D Mid, Finland) (fig. 1). 


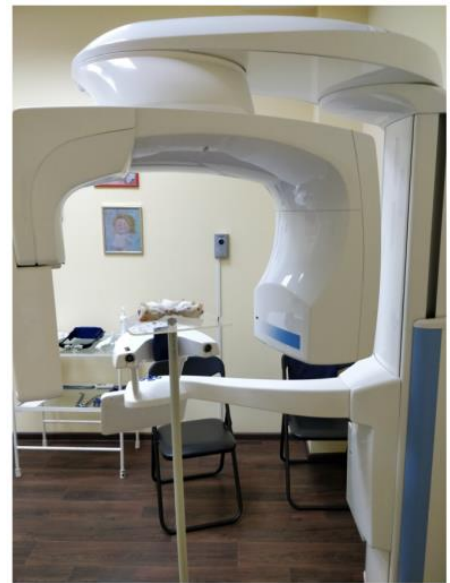

a

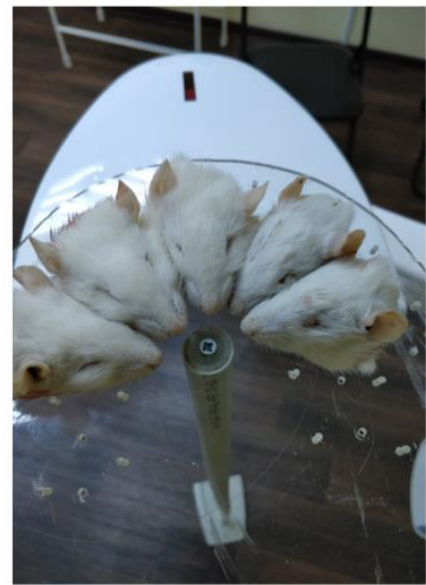

b

Fig. 1. The method of computerized tomography of rats' heads: a - Planmeca ProMax 3D Mid, b - the rats' heads dislocation on the table

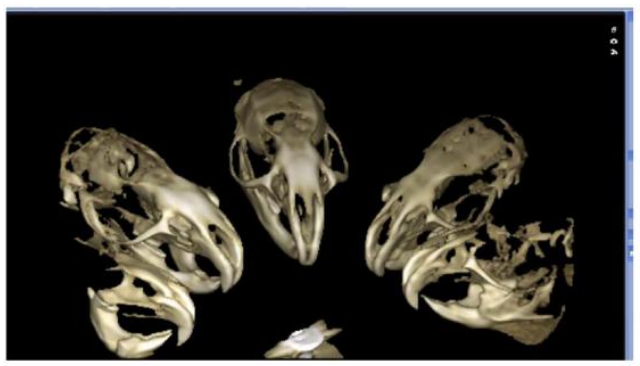

a

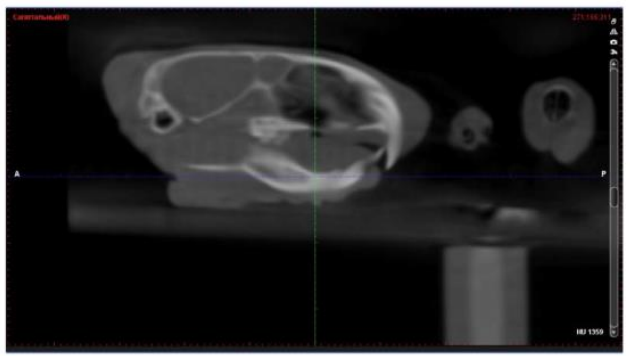

b

Fig. 2. The computed tomography of rats' mandibles:

$a$ - general view, $b$ - measurement of the bone mineral density (BMD) 
Results and discussion. According data of computer tomography (fig. 2) it was established that animals of the main group have more pronounced phenomena of increased osteoresorption and a decrease in the mineral density of the jaws' bone tissue in comparison with the control. Thus, according to a computer tomography study of rats' mandibles, the average values of the bone mineral density index (BMD) in cortical layer of mandible decreased in the main group to $1100.0 \pm 120.0 \mathrm{HU}$ versus $1320.0 \pm 125.5 \mathrm{HU}$ in the control group ( $>0.05)$.

Conclusions. The obtained results proved greater effectiveness of the proposed method of modeling periodontitis against the background of experimental type-2 diabetes mellitus. So, this experimental model of general periodontitis can be used for development and approbation of new methods of treatment.

\section{References:}

1. Данилевський М. Ф., Борисенко А. В., Антоненко М. Ю. Терапевтична стоматологія / за ред. А. В. Борисенка. ВСВ «Медицина», 2018. Т. 3: Захворювання пародонта. 624 с.

2. Мащенко И. С., Гударьян А. А., Дорогина А. С. Причины устойчивости основных пародонтальных возбудителей к антибактериальной терапии у больных с быстропрогрессирующим генерализованным пародонтитом. Вісник стоматологии. 2013. № 4. С. 35-41.

3. Nascimento G. G., Leite F. R. M , Vestergaard P. Does diabetes increase the risk of periodontitis? A systematic review and meta-regression analysis of longitudinal prospective studies. Acta Diabetol. 2018. № 55 (7). P. 653-667.

4. WuY.Y., Xiao E., Graves D. T. Diabetes mellitus related bone metabolism and periodontal disease. International Journal of Oral Science. 2015. № 7. P. 63-72.

5. Гударьян А. А., Мащенко И. С., Шандыба С. И. Генерализованный пародонтит у больных сахарным диабетом 2 типа: тактика и особенности хирургического лечения. Lambert Academic Publishing, 2019. $157 \mathrm{c}$.

6. Меладзе И. Н. Воспалительно-деструктивные изменения в тканях пародонта крыс при экспериментальном метаболическом синдроме и пути их устранения. Современная стоматология. 2016. № 4. С. 73-75.

7. Спосіб моделювання пародонтиту з ураженням сполучної тканини пародонта : пат. 67897 Україна: МПК (2012.01) А 61 Р 31/00. № 2011 09537; заявл. 29.07.2011; опубл. 12.03.2012, Бюл. № 5.5 с.

8. Szkudelski T. Streptozotocin-nicotinamide-induced diabetes in the rat. Characteristics of the experimental model. Experimental Biology and Medicine. 2012. Vol. 237. № 5. P. 481-490. 